\title{
HAEMATOLOGICAL EVALUATION OF SPRAGUE-DAWLEY RATS INFECTED WITH PASTEURELLA MULTOCIDA AND ADMINISTERED BDELLOVIBRIO BACTERIOVORUS (ATCCTM 1534) AS THERAPY
}

\author{
${ }^{*}$ Sar, T. T., ${ }^{2}$ Umeh, U. E. and ${ }^{3}$ Amali, 0.
}

\author{
${ }^{*} 123$ Department of Biological Sciences, University of Agriculture, Makurdi, Benue State, Nigeria \\ *Phone: +2347064927606; *Email: terdzungwe@yahoo.com \\ Phone: +2348026980137; Email: jceu1@yahoo.com \\ Phone:+2347037849816; Email: okwomali@yahoo.co.uk
}

\begin{abstract}
The effects on haematological parameters of Sprague-Dawley rats infected (challenged) by the injection of pathogenic Pasteurella multocida and the administration of Bdellovibrio bacteriovorus $\left(\mathrm{ATCC}^{\mathrm{TM}} 1534\right)$ as therapy, occasioned by the consideration of its use as an alternative to antibiotics, due to the high rate of bacterial resistance to current clinically used antibiotics was investigated. A total of 60 rats, divided into 5 groups ( 4 experimental groups and 1 control group) of 12 rats each were used in this study. The first group of 12 rats were injected subcutaneously with one millilitre of $1 \times 10^{8} / \mathrm{ml}$ B. bacteriovorus (ATCC ${ }^{\mathrm{TM}}$ 1534). The second group of 12 rats were injected with one millilitre $10^{8} / \mathrm{ml}$ of $P$. multocida in saline. One millilitre each of $10^{8} / \mathrm{ml}$ of both P. multocida and B. bacteriovorus (ATCC ${ }^{\mathrm{TM}} 1534$ ) were injected into another set of 12 rats in the third group. The third group of 12 rats were injected once intra-muscularly, in the hind flank muscle, with $2 \mathrm{mg} / \mathrm{kg}$ of Ketamine Hydrochloride. And lastly, one set of 12 rats were not injected with any bacteria served as control. In all cases, observed haematological data were analysed from the experimental rats after 168 hours (except rats which were injected with $2 \mathrm{mg} / \mathrm{kg}$ ketamine hydrochloride, used as anaesthetic, (at sacrifice), and compared with the haematological profiles of the 12 control rats. Results shows a reduction of mortality from 9 to $1(88.8 \%)$ of rats challenged with $P$. multocida over those inoculated with B. bacteriovorus and $P$. multocida was observed. WBC counts were higher $\left(4.12 \times 10^{3} / \mu \mathrm{L}\right)$ in B. bacteriovorus and P. multocida over WBC counts in control rats which served as WBC reference values. Though, not statistically significant $(\mathrm{ANOVA}=p>0.05)$. In a similar comparison, $\mathrm{RBC}$ counts $\left(6.5 \mathrm{x} 10^{3} / \mu \mathrm{L}\right)$ were lower than observed in control rats, while platelet counts $\left(1138 \times 10^{3} / \mu \mathrm{L}\right)$ were higher than values in controls, however, this was statistically significant. Moreover, haemoglobin concentrations were lower $(11.7 \mathrm{~g} / \mathrm{dL})$ than in control rats. Though there were slight variations in haematological profiles from reference values, it was concluded that $B$. bacteriovorus seems to have no life-threatening effect on haematology of rats. However, evaluations such as observed platelet increases on inoculations of B. bacteriovorus, need to be addressed before the promise of its in vivo use in controlling Gram-negative infection in animals and humans can be tapped.
\end{abstract}

Keywords: bdellovibrio bacteriovorus, control, haematological, Pasteurella multocida, rats

LICENSE: This work by Open Journals Nigeria is licensed and published under the Creative Commons Attribution License 4.0 International License, which permits unrestricted use, distribution, and reproduction in any medium, provided this article is duly cited.

COPYRIGHT: The Author(s) completely retain the copyright of this published article.

OPEN ACCESS: The Author(s) approves that this article remains permanently online in the open access (OA) mode.

QA: This Article is published in line with "COPE (Committee on Publication Ethics) and PIE (Publication Integrity \& Ethics)". 


\section{INTRODUCTION}

Bdellovibrio are Gram-negative, vibroid and tiny bacteria (between $0.3-0.5 \mu \mathrm{m}$ by $1.4-2.5 \mu \mathrm{m}$ ). They are motile by single sheathed polar flagella. They are predatory on other Gram-negative bacteria. Using degradative enzymes, they create pores in host cell walls, enter the periplasm, and use the cytoplasmic contents of prey cells as nutrients for growth and reproduction. Finally, they burst the host cell envelopes, which lead to the host cell (prey) deaths (Megan et al., 2003).

Bdellovibrio interest microbiologists as it has potential for use as bio-controls of many pathogenic Gramnegative microorganisms. In addition, studies on enzymes they use to degrade host cell walls give insight into targets in prey cells that have been successful points of attack from an evolutionary viewpoint and can be used for design of antimicrobial agents (Lambert et al., 2006).

Though, other predatory bacteria e.g. Micavibrio, are also being studied for in vivo predatory activity, Bdellovibrio stands out because of a number of unique properties, such as having a wide variety of Gram-negative prey, which is a highly desirable quality of a good microbial control agent. Bdellovibrio have been isolated from water bodies and soils from parts of Benue State, Nigeria (Sar et al., 2015; Sar et al., 2016), and from the gastro-intestinal tracts of animals and humans (Houmsou et al., 2010). Soon, Bdellovibrio may have practical antimicrobial therapeutic applications in medical science (Harini et al., 2013).

\section{MATERIALS AND METHODS}

A total of 60 (30 of either sex) randomly selected Sprague Dawley rats, approximately 16 weeks old were used. They were housed under ambient temperatures of about $25^{\circ} \mathrm{C} \pm 5{ }^{\circ} \mathrm{C}$, and relative humidity (RH) of about $55 \% \pm 5 \%$. Feed and water were supplied ad libitum.

All rats used were from the same litter thus, genetically related, at similar stages of development, and received similar treatments, such that within limits, haematological parameters from them would originally have insignificant variations, such that any major changes or shifts observed should be due to experimental treatments.

To determine the haematological effects on rats, a group of 12 rats were each subcutaneously (abdominally)

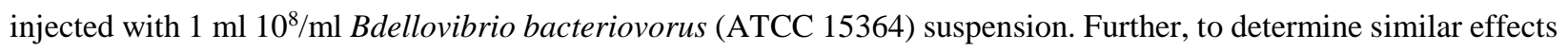
of Pasteurella multocida, another set of 12 rats were injected with one millilitre of $10^{8} / \mathrm{ml}$ suspension of $P$. multocida. For investigating in vivo effects of B. bacteriovorus on $P$. multocida, another set of 12 rats were injected first with $P$. multocida, then within a minute or two, injected with $1 \mathrm{ml}$ of $1 \times 10^{8} \mathrm{PFU} / \mathrm{ml}$ B. bacteriovorus (ATCC 1534) suspension.

To evaluate the haematological effects of Ketamine Hydrochloride, an anaesthetic used on the rats during blood collection and sacrifice, a control group of 12 rats were injected once intra-muscularly, in the hind flank muscle, with $2 \mathrm{mg} / \mathrm{kg}$ of Ketamine Hydrochloride. These rats were sacrificed as soon as the drug took effect. A second control group was made up of 12 rats not injected with pathogen, B. bacteriovorus or anaesthetic.

Apart from anaesthetic, all other injections were subcutaneous - a fold of abdominal skin was pinched and lifted for each injection. All injections were given once every 24 hours, for 168 hours, after which period the rats were bled (fur over the sternum was thoroughly cleaned with tincture of iodine, and one millilitre of blood withdrawn 
by cardiac puncture) for haematological analysis. All injected rats were observed for pathological, physiological and physical signs of disease, including mortality.

\section{DETERMINATION OF BACTERIAL PATHOGENICITY}

P. multocida was serially diluted in physiological saline. The count of the bacteria in each dilution was determined by McFarland's standard. Six animals each were subcutaneously injected with one dilution of inocula. Mortality was considered a sign of infection. Live rats were sacrificed at 168 hours for gross anatomical lesions/histology, and the $\mathrm{LD}_{50}$ calculated according to the method of Reed-Muench (Saganuwan, 2015).

\section{BACTERIAL COUNTS DETERMINATION}

SD 2303 McFarland Standard 3.0 and the test bacterial suspension were employed using model WPA CO 7500 Colorimeter. The McFarland Equivalence Standards was used to estimate bacterial quantities in suspensions. These produced expected bacterial plate counts and were used for the tests.

Further, bacterial counts obtained by McFarland's standard were run through Invitrogen ${ }^{\mathrm{TM}}$ Countess $^{\mathrm{TM}}$ (USA) Automated Cell Counter (ACC). Numbers of viable cells were automatically obtained and recorded.

\section{AUTO-ANALYSIS OF BLOOD PARAMETERS}

The analysis was carried out by Mindray ${ }^{\mathrm{TM}}$ model BC 5300 (China) auto-haematology analyzer. Parameters determined were red blood cell (RBCs), platelet (PLT), white blood cell (WBC) counts and haemoglobin (HGB) concentration.

\section{STATISTICAL ANALYSIS}

Data were analyzed using IBM SPSS version 23.0 (2015). ANOVA and post hoc multiple comparisons were used to test for group differences between haematological parameters. All tests were considered significant at $p \leq 0.05$ level of probability.

\section{RESULTS \\ MORTALITY RATES}

A total mortality rate of $75 \%(\mathrm{n}=9 ; 5$ male and 4 female) was observed in rats injected with P. multocida, and $8.3 \%$ (n=1 female rat) in those injected with both P. multocida and B. bacteriovorus (Figure 1). Twenty-four hours after injection with $P$. multocida, there was a mortality rate of $41.7 \%$ (5 rats). After 96 hours (4 days) of injections, there was a mortality rate of $66.7 \%$ ( 8 rats), which rose to $75 \%$ by 168 hours of injection. After injecting rats with both $P$. multocida and B. bacteriovorus however, mortality fell by $88.8 \%$ compared with rats injected with only $P$. multocida. 


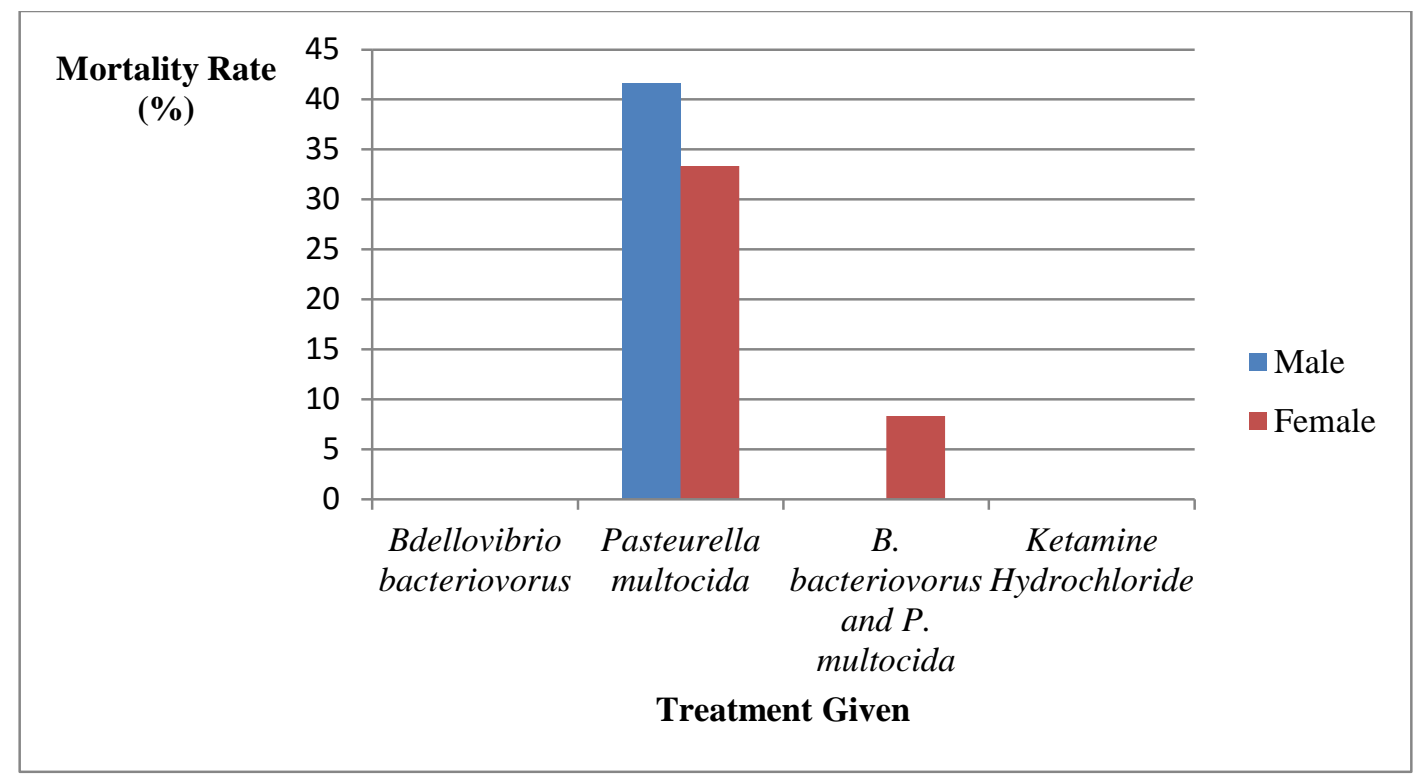

Figure 1: Mortality Rates in Sprague Dawley Rates Injected with B. bacteriovorus, and with P. multocida and B. bacteriovorus + P. multocida

\section{CHANGES IN HAEMATOLOGICAL PARAMETERS}

\section{WHITE BLOOD CELL (WBC) COUNTS}

Table I shows changes in haematological parameters in rats injected with B. bacteriovorus, with P. multocida and with both $P$. multocida and $B$. bacteriovorus. $P$. multocida injected rats had a WBC count of $7.50 \times 10^{3} / \mu \mathrm{L}$, while rats injected with both $B$. bacteriovorus and $P$. multocida had a value of $4.12 \times 10^{3} / \mu \mathrm{L}$, indicating a lower count of $3.38 \times$ $10^{3} / \mu \mathrm{L}$ or $45.1 \%$. However, no statistically significant difference in WBC counts was found between rats injected with only B. bacteriovorus and control rats not injected.

\section{RED BLOOD CELL (RBC) COUNTS}

When injected with $P$. multocida, RBC counts $\left(7.00 \times 10^{6} / \mu \mathrm{L}\right)$ were higher compared with counts $\left(6.50 \times 10^{6} / \mu \mathrm{L}\right)$ in rats injected with both $B$. bacteriovorus and $P$. multocida (Table I) indicating a decrease of $0.50 \times 10^{6} / \mu \mathrm{L}(7.14 \%)$. Compared with control rat's RBC values, all injected rats had lower counts. Statistically, RBC counts of rats injected with $B$. bacteriovorus were not significantly different from un-injected control rats. Similarly, RBC counts between rats injected with $P$. multocida only and the un-injected controls were significantly different. Again, RBC counts differed significantly between rats injected with only $P$. multocida, and rats injected with both $P$. multocida and $B$. bacteriovorus.

\section{PLATELET (PLT) COUNTS}

$P$. multocida injected rats had a platelet count of $1004 \times 10^{3} / \mu \mathrm{L}$, which increased to $1138 \times 10^{3} / \mu \mathrm{L}$ in the $B$. bacteriovorus and P. multocida injected rats, indicating an increase of $134 \times 10^{3} / \mu \mathrm{L}(13.4 \%)$. Both groups showed counts higher than control rat counts (Table I). PLT counts differed significantly between rats injected with $B$. 
bacteriovorus and un-injected controls. Similarly, PLT counts differed significantly between rats injected with $P$. multocida, and rats injected with both P. multocida and B. bacteriovorus and un-injected controls.

\section{HAEMOGLOBIN (HGB) CONCENTRATION}

P. multocida injected rats had a HGB concentration of $12.10 \mathrm{~g} / \mathrm{dL}$, which decreased to $11.70 \mathrm{~g} / \mathrm{dL}$ in the Bdellovibrio and P. multocida, treated rats, a decrease of $0.40 \mathrm{~g} / \mathrm{dL}$ (3.31\%) (Table I). Haemoglobin concentration in rats injected with only B. bacteriovorus was significantly different from un-injected controls. HGB concentration also differed significantly between rats injected with only P. multocida and those injected with both P. multocida and $B$. bacteriovorus. Similarly, significant difference in HGB concentration was found in rats injected with $P$. multocida and un-injected control rats.

Table I: Haematological changes in rats injected with $P$. multocida, and with $P$. multocida and $B$. bacteriovorus

\begin{tabular}{|c|c|c|c|c|c|c|c|c|}
\hline \multirow[b]{2}{*}{$\begin{array}{l}\text { Organism Injected } \\
\text { (Groups) }\end{array}$} & \multicolumn{8}{|c|}{ Parameter Analysed } \\
\hline & $\begin{array}{l}\text { WBC } \\
\left(x 10^{3} / \mu L\right)\end{array}$ & $S D$ & $\begin{array}{l}\mathrm{RBC} \\
\left(x 10^{6} / \mu L\right)\end{array}$ & $S D$ & $\begin{array}{l}\text { PLT } \\
\left(x 10^{6} / \mu L\right)\end{array}$ & $S D$ & $\begin{array}{l}\mathrm{HGB} \\
(g / d L)\end{array}$ & $S D$ \\
\hline B. bacteriovorus & 5.52 & \pm 3.5 & 7.31 & \pm 0.6 & 818 & \pm 292.3 & 13.0 & \pm 1.04 \\
\hline P. multocida (a) & 7.50 & \pm 0.7 & 7.0 & \pm 0.09 & 1004 & \pm 69.2 & 12.1 & \pm 0.11 \\
\hline $\begin{array}{l}\text { P. multocida }+ \\
\text { B. bacteriovorus (b) }\end{array}$ & 4.12 & \pm 1.4 & 6.5 & \pm 1.1 & 1138 & \pm 366.8 & 11.7 & \pm 1.5 \\
\hline Difference $(a-b)$ & 3.3 & \pm 1.72 & 0.5 & \pm 0.3 & -134 & \pm 67.0 & -0.4 & \pm 0.2 \\
\hline Percent Change & 45.1 & - & 7.14 & - & 13.4 & - & 3.31 & - \\
\hline *Reference Value & 3.82 & - & 8.21 & - & 916 & - & 16 & - \\
\hline
\end{tabular}

\section{DISCUSSION}

An interesting result of the mitigating effects of Bdellovibrio on $P$. multocida infection was the sharp drop in mortality of rats injected with both P. multocida and B. bacteriovorus. In vivo predation of pathogen by B. bacteriovorus could have accounted for a reduction in mortality rates. In a similar finding, Willis et al. (2016) injected Zebrafish larvae with Shigella flexneri alongside B. bacteriovorus and found that Bdellovibrio effectively predated in vivo on S. flexneri in the Zebrafish host, leading to reduced pathogen concentration and a drop in host mortality. Hobley et al. (2006) have also demonstrated by mathematical modelling that Bdellovibrio is capable of effective in vivo predation in the presence of cellular debris and decoys within living systems.

Higher WBC counts in rats injected with P. multocida than in those injected with only B. bacteriovorus, and those injected with both B. bacteriovorus and P. multocida, which counts were all higher than in control un-injected 
rats are not isolated findings but indicate that WBCs, which typically increase in numbers on challenge with certain threshold quantities of foreign immunogenic materials, such as pathogens or other foreign substances, may have been triggered by the injected bacteria. Studies by Monnappa et al. (2016) showed that B. bacteriovorus and other predatory bacteria elicit mild immunologic responses in animals. If this is the case, then injecting rats with $B$. bacteriovorus would have led to the observed rise in WBC levels. From this premise, it follows therefore that injections of both $B$. bacteriovorus and pathogen would have produced an even greater synergistic response occasioned by the sum of the separate immunologic responses to both $P$. multocida and B. bacteriovorus injection.

Shatzkes et al. (2016) evaluated the ability of predatory bacteria in attenuating Klebsiella pneumoniae burden in rat lungs and found that the predatory bacteria reduced pathogen burden and caused transient elevated levels of inflammatory cytokines. It is therefore not unusual to have found a WBC increase in rats injected with $B$. bacteriovorus. Furthermore, work by Willis et al. (2016) also found that B. bacteriovorus injected into Zebrafish larvae was eventually eliminated by host neutrophils and macrophages, which recognised and engulfed the predator. All these point to the fact that Bdellovibrio causes immune responses in animal host as also found in this study.

B. bacteriovorus elicited increase of WBC counts could be an added advantage in that the higher numbers of circulating WBC would help in warding off bacterial infections (Willis et al., 2016). Successful elimination of pathogens, even if not directly due to predation by B. bacteriovorus, would be more desirable than use of chemotherapeutic alternatives with the attendant unpleasant side effects and adverse reactions frequently associated with their use.

While a plausible explanation for the observation that B. bacteriovorus injection lowered $\mathrm{RBC}$ counts in rats is hard to come by, it is likely that the low RBC counts may be related to the high WBC counts which could have led to anaemia or even a leukaemia-like situation, which could be harmful (Merchant et al., 2004).

An implication of the observation that rats injected with only Bdellovibrio had lower platelet counts than control rats is that clotting may be compromised and periods of bleeding during injury increased in recipients of $B$. bacteriovorus therapy. It is possible that certain undetermined factors, components or substances produced by Bdellovibrio were released into the bloodstream and could have led to a depletion of platelets. In this study, the presence of such components was not investigated, and remains to be determined.

However, the higher platelet counts in rats injected with both B. bacteriovorus and P. multocida than found in controls may reflect as in similar findings which observed that platelet counts in humans' increase on infections or certain diseases (Hsu et al., 2010). Therefore, inoculating rats with both the B. bacteriovorus and P. multocida probably led to the high platelet counts observed.

The consistently lower haemoglobin concentrations in rats injected with P. multocida and with combinations of $B$. bacteriovorus and P. multocida than in un-injected controls may be related to the low RBC counts, as haemoglobin in all mammals is transported by the RBCs. Also, according to Marković et al. (2011) several substances may affect rat haematologic parameters, however, the exact mechanism which caused lowered haemoglobin levels, observed in this study, remains unclear. 


\section{CONCLUSION}

It was shown that B. bacteriovorus administered to rats challenged with a pathogenic Gram-negative bacterium, $P$. multocida led to a sharp reduction in their mortality rates, which suggests that the organism mitigated the pathogen's morbid effects. However, certain effects associated with injections of B. bacteriovorus, such as differences in WBC, reduction in RBC counts and haemoglobin concentration, as well as increased platelet counts, though mild and perhaps not clinically important requires further investigation and should be fully accounted for, to prepare grounds for eventual use Bdellovibrio for treatment of Gram-negative bacterial infections in animals. 


\section{REFERENCES}

Hsu, C.W., Lin, J.L., Lin-Tan, D.T., Yen, T.H. and Chen, K.H. (2010). White blood cell count predicts all-cause, cardiovascular disease-cause and infection-cause one-year mortality of maintenance hemodialysis patients. Therapeutic Apheresis and Dialysis. 14(6):552-9. Doi: 10.1111/j.1744-9987.2010.00849. x.

Harini, K., Ajila, V. and Hegde, S. (2013). Bdellovibrio bacteriovorus: A future antimicrobial agent? Journal of Indian Society of Periodontology. (6):823 -825. doi: 10.4103/0972-124X.124534.

Hobley, L., King, J. R. and Sockett, R. E. (2006). Bdellovibrio predation in the presence of decoys: three-way bacterial interactions revealed by mathematical and experimental analyses. Applied and Environmental Microbiology. 72(10): 6757 - 6765. doi: 10.1128/AEM.00844-06

Houmsou, R. S., amuta, E. U. and Sar, T. T. (2010). Impact of urbanization on parasitic infections in developing countries. Reviews in Infection. 1(1): 38 - 41

Lambert, C., Morehouse, K.A., Chang, C.Y and Sockett, R. E. (2006) Bdellovibrio: growth and development during the predatory cycle. Current Opinion in Microbiology 9 (6): 639-644.

https://doi.org/10.1016/j.mib.2006.10.002

Marković, D., Žižić, J., Djačić, D., Obradović, A., Curčić, M., Cvetković, D., Đorđević, N., Ognjanović, B. and Štajn, S. (2011). Alteration of oxidative stress parameters in red blood cells of rats after chronic in vivo treatment with cisplatin and selenium. Archives of Biological Sciences 63 (4): 991 - 999. DOI: 10.2298/ABS1104991M

Megan, N. E., Mark, O. N., Lin, K. D., Eilaine, L. and Spain, E. M. (2003) investigations into the life cycle of the bacterial predator Bdellovibrio bacteriovorus at an interface by atomic force microscopy Biophysical Journal 84(5): 3379 -3388. Doi: 10.1016/S0006-3495(03)70061-7

Merchant, M. A. and Modi, D. N. (2004). Acute and chronic effects of aspirin on haematologic parameters and hepatic ferritin expression in mice. Indian Journal of Pharmacology 36 (4): 226 - 230. Retrieved on $7^{\text {th }}$ July, 2017 from: www.medind.nic.in/ibi/t04/i4/ibit04i4p2226.pdf.

Monnappa, A. K., Wasimul, B., Seong, Y.C. and Robert, J.M. (2016). Investigating the response of human epithelial cells to predatory bacteria. Scientific Reports Nature Publishing Group (6):33485. doi:10.1038/srep33485

Saganuwan, A. S. (2015). Toxicology: the basis for development of antidotes. Toxicology: Open Access 1:1 e101. doi:10.4172/2476-2067.1000e101

Sar, T.T., Umeh, E. U. and Akosu, D. D. (2015). Occurrence, detection and isolation of Bdellovibrio spps from some fresh water bodies in Benue State, Nigeria. Microbiology Journal 5 (1): 21 - 27 ISSN 2153 - 0696/DOI: $10.3923 / \mathrm{mj} .2015 .21 .27$

Sar, T. T., Umeh, E. U., Amali, O. and Akosu, D. D. (2016). Determining the presence of Bdellovibrio spps in soils from parts of Benue State, Nigeria. International Journal of Environmental Sciences 5(9): 1 - 5 ISSN: 2319

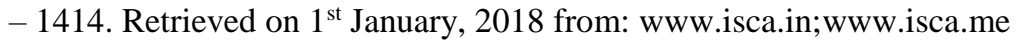

Shatzkes, K.., Singleton, E., Tang, C., Zuena, M., Shukla, S., Gupta, S., Dharani, S., Onyile, O., Inaggio, J., Connell, N. and Kadouri, D. (2016). Predatory bacteria attenuate Klebsiella pneumoniae burden in rat lungs. mBio 7(6). doi: 10.1128/mBio.01847-16

Willis, A. R., Moore, C., Mazon-Moya, M., Krokowski, S., Lambert, C., Robert, T., Mostowy, S. and Sockett, R. E., (2016). Injections of predatory bacteria work alongside host immune cells to treat Shigella infection in Zebrafish larvae. Current Biology 26(24): 3343-3351. DOI: http://dx.doi.org/10.1016/j.cub.2016.09.067 